\title{
Batı Marmara Bölgesindeki Bir Üniversite Hastanesinde Son Üç Yıllık Dönemdeki Jinekolojik Malignite Vakalarının Retrospektif Analizi
}

\section{Retrospective Analysis of Gynecological Malignancy Cases in the Last Three Years in A Uni- versity Hospital in the Western Marmara Region}

\author{
${ }^{1}$ Sevde ÇUBUKÇU AKSU, ${ }^{2}$ Pelin PALAS KARACA, ${ }^{3}$ Mine İSLIMYY TAŞKIN \\ ${ }^{1}$ Balıkesir Üniversitesi Sağlık Bilimleri Fakültesi, Doğum ve Kadın Sağlığı Hemşireliği Anabilim Dalı, Balıkesir, Türkiye \\ ${ }^{2}$ Balıkesir Üniversitesi Sağlık Bilimleri Fakültesi, Ebelik Bölümü, Balıkesir, Türkiye \\ ${ }^{3}$ Balıkesir Üniversitesi Tıp Fakültesi, Kadın Hastalıkları ve Doğum Anabilim Dalı, Balıkesir, Türkiye
}

Sevde Çubukçu Aksu: https://orcid.org/0000-0001-7749-8474

Pelin Palas Karaca: https://orcid.org/0000-0002-9336-6209

Mine İslimye Taşkın: https://orcid.org/0000-0001-9199-1679

\section{ÖZ}

Amaç: Çalışmada Batı Marmara bölgesinde bir üniversite hastanesinde opere edilen jinekolojik malignite vakalarının risk faktörleri açısından retrospektif değerlendirilmesi amaçlanmıştır.

Materyal ve Metot: Araştırmanın gerçekleştirildiği hastanede Ağustos 2017-Ağustos 2020 tarihleri arasında kayit sisteminden vakaların sosyo-demografik bilgileri, obstetrik ve jinekolojik anamnez, uygulanması kararlaşt1rilan tanı ve tedavi yöntemleri ile postoperatif histopatolojik bulguları incelenmiştir.

Bulgular: Kadınların \% 64,2'sinin serviks kanseri iken $\% 23,9$ 'unun endometrium kanseri \%11,9'unun ise over kanseri olduğu belirlenmiştir. Risk faktörleri incelendiğinde; servikal kanserli vakaların \%35,6'sında ilk cinsel aktivite 18 yaş altı olup \%64,3'ünün kötü hijyen koşullarına sahip olduğu, endometrium kanserli vakaların \%38,5'inin beden kitle indeksi $30 \mathrm{~kg} / \mathrm{m} 2$ üzerinde ve \%48'inin en az bir kronik hastalığı olduğu, over kanserli vakaların ise \% 46,1'inin infertilite tedavisi aldığı belirlenmiştir.

Sonuç: $\mathrm{Bu}$ çalışmanın sonucunda çalışmaya alınan vakaların başvuru yakınmaları ve risk faktörleri ile ilgili elde edilen veriler değerlendirildiğinde, özellikle çevresel risk faktörleri ve kişinin yaşam tarzının kanserlerin ortaya çıkmasında önemli etkisi olduğu saptanmıştır.

Anahtar Kelimeler: Kanser epidemiyolojisi, over kanseri, serviks kanseri, endometrium kanseri

\begin{abstract}
Objective: In this study, it was aimed to retrospectively evaluate gynecological malignancies operated in a university hospital in West Marmara region in terms of risk factors.

Materials and Methods: In the hospital where the study was conducted, the socio-demographic information of the cases, obstetric and gynecological anamnesis, the diagnosis and treatment methods decided to apply, and postoperative histopathological findings were examined from the registry system between August 2017 and August 2020.
\end{abstract}

Results: It was determined that $64.2 \%$ of women had cervical cancer, while $23.9 \%$ had endometrial cancer and $11.9 \%$ had ovarian cancer. When the risk factors are examined; In $35.6 \%$ of cervical cancer cases, first sexual activity is under the age of $18,64.3 \%$ of them have poor hygiene conditions, $38.5 \%$ of endometrial cancer cases have body mass index over $30 \mathrm{~kg} / \mathrm{m} 2$ and $48 \%$ have at least one chronic disease, ovarian cancer $46.1 \%$ of the cases were determined to receive infertility treatment.

Conclusion: As a result of this study, when the data obtained regarding the presentation complaints and risk factors of the cases included in the study were evaluated, it was found that especially environmental risk factors and the lifestyle of the person had an important effect on the occurrence of cancers.

Keywords: Cancer epidemiology, cervical cancer, ovarian cancer, endometrial cancer

Yayın Bilgisi / Article Info:

Gönderi Tarihi/ Received: 17/12/2020

Kabul Tarihi/ Accepted: 07/07/2021

Online Yayın Tarihi/ Published: 05/09/2021

\footnotetext{
Sorumlu Yazar / Corresponding Author:

Sevde Çubukçu Aksu

Balıkesir Üniversitesi Çağış Yerleşkesi Sağlık Bilimleri Fakültesi

Doğum ve Kadın Sağlığı Hemşireliği Anabilim Dalı, Balıkesir, Türkiye

Tel: +90266 2440010 / 05054998049

E-mail: sevde.c@gmail.com / sevdeaksu@balikesir.edu.tr
}

Atıf / Cited: Çubukçu Aksu S ve ark. Batı Marmara Bölgesindeki Bir Üniversite Hastanesinde Son Üç Yıllık Dönemdeki Jinekolojik Malignite Vakalarının Retrospektif Analizi. Online Türk Sağllk Bilimleri Dergisi 2021;6(3):361-367. doi: 10.26453/otjhs.842600 


\section{GíRiş}

Kanser dünya ve ülkemizde prevalansı giderek artan önemli bir halk sağlığı sorunu olması yanında fiziksel, psikososyal ve ekonomik birçok sıkıntıya yol açan kronik bir hastalık olarak da görülmektedir. ${ }^{1-3}$ Dünya genelinde 2016 y1lında 17,2 milyon kanser vakası ve 8,9 milyon kansere bağlı ölüm olduğu belirlenmiştir. Mortaliteye en çok neden olan kanser türleri sırası ile meme, solunum sistemi ve kolorektal kanserleri olup özellikle kanser gelişim riskinin cinsiyetler arası farklılık gösterdiği bilinmektedir. ${ }^{4}$ Amerikan Kanser Birliği 2018 yılı verilerine göre kadınlarda ilk 10 sırada; meme, akciğer, barsak, uterus, tiroid, melonoma, non-hodgin lenfoma, pankreas, lösemi, böbrek ve renal pelvis kanserleri görülmektedir. ${ }^{5}$ Türkiye Kanser İstatistikleri verilerine göre 2016 yılındaki kanser hızı erkeklerde yüz binde 259,9 iken kadınlarda bu oran yüz binde 183,2'dir. Ülkemizdeki kadınlarda görülen ilk beş kanser türü, dünyadaki pek çok ülke verileri ile benzerlik göstermekte olup bunların meme, triod, kolorektal, uterus korpusu ve solunum kanserleri olduğu belirlenmiştir. ${ }^{6}$

Jinekolojik kanserler; cerrahi operasyonlar, kemoradyasyon terapiler gerektirmeleri ve yaşam kalitesi ile psikososyal hayat üzerindeki olumsuz etkilerinden dolayı morbidite ve mortalite açısından oldukça önemlidir. Küresel Kanser İnsidansı, Mortalite ve Prevelansı (GLOBOCAN) 2018 verilerine göre jinekolojik kanserlerde dünya genelinde 1,2 milyon yeni vaka olup 610 bin kadının hayatını kaybettiği belirlenmiştir. ${ }^{7}$ Türkiye istatistiklerine göre ise jinekolojik kanserler tüm kadın kanserlerinin \%11,2'ni oluşturmaktadır. Gültekin ve ark. ${ }^{8}$ ülkemizde yaptı̆̆ 1 çalışmada en sık görülen jinekolojik kanserin uterus korpus kanserleri olup bunu over ve servikal karsinom izlediği saptanmıştır.

Jinekolojik kanserlerde kadınlar çoğunlukla akıntı, kilo kaybı, anormal uterin kanama, pelvik ağrı, sindirim ve üriner sistem yakınmaları ile sağlık kuruluşlarına başvurmaktadır. Hormonal ve reprodüktif nedenler (doğum sayısı, emzirme, menarş, koit yaşı, menapoz, hormon tedavileri vb), geçirilmiş kanser öyküsü, aile öyküsü, enfeksiyöz nedenler, yaş, sigara kullanımı, obezite gibi birçok etken jinekolojik kanserlerin risk faktörleri içinde yer almaktadır. ${ }^{9-12}$

Jinekolojik kanserler erken teşhis ve tedaviyle önlenebilir hastalıklardır. Erken evrelerde kanser tanısı alma, yapılacak olan tedavinin daha başarılı olmasını sağlamaktadır. ${ }^{13}$

Özellikle kadın sağlığının ele alınmasında iki önemli nokta vardır. Birincisi kadınların anatomik farklılık- larının neden olduğu morbidite ve mortalite yükü; ikincisi kadınların toplumda cinsiyetleri nedeniyle etkilendikleri yaşam tarzına bağlı ortaya çıkan risklerdir. ${ }^{14}$

Jinekolojik kanserlerle ilişkili risk faktörlerini belirleme, tanılama ve genetik yatkınlık konularında donanımlı sağlık profesyonellerinin yetiştirilmesi, kadın kanserlerine yönelik bireysel programlar geliştirilmesi kadın kanserleri konusunda geriye kalan birçok gizemin çözülmesine olanak sağlayacaktır.

Bu çalışmada Batı Marmara bölgesinde bir üniversite hastanesi Doğum ve Kadın Hastalıkları Kliniğinde 2017-2020 tarihleri arasında opere edilen jinekolojik malignitelerin histopatolojik ve kişisel, tıbbi öykü ve yaşam biçimine ait risk faktörleri açısından retrospektif değerlendirilmesi amaçlanmıştır.

\section{MATERYAL VE METOT}

Bu araştırma için Balıkesir Üniversitesi Tıp Fakültesi Klinik Araştırmalar Etik Kurul Başkanlığı'ndan Etik Kurul Başkanlığı'ndan (Tarih=22.07.2020, karar no=2020/115) ve ilgili kurumdan yazılı izin alınmıştır. Çalışma Helsinki Bildirgesi'ne uyularak etik kurallar çerçevesinde yapılmıştır.

Araştırma retrospektif bir çalışma olarak planlandı. Araştırmanın evrenini Batı Marmara bölgesindeki bir üniversite hastanesi Doğum ve Kadın Hastalıklar1 Kliniği'ne başvuran ve endometrium, over ve serviks kanser tanısı kadınlar oluşturdu. Örneklemini ise; araştırmanın gerçekleștirildiği hastanede Doğum ve Kadın Hastalıkları Kliniğinde Ağustos 2017Ağustos 2020 yılları arasında jinekolojik malignite endikasyonu nedeni ile opere edilmiş ve yeterli yazı1 dokümanına ulaşılabilen 109 vaka oluşturmuştur. Araştırmanın gerçekleştirildiği hastanede belirtilen süre içerisinde kayıt sisteminden vakaların sosyodemografik bilgileri, obstetrik ve jinekolojik anamnez, uygulanması kararlaştırılan tanı ve tedavi yöntemleri ile postoperatif histopatolojik bulguları incelenmiştir.

İstatistiksel Analiz: Araştırmada elde edilen verilerin analizi için SPSS 20 (Statistical Package for the Social Sciences for Windows 20) paket programı kullanılmıştır. Veriler değerlendirilmesi için tanımlayıcı istatistiksel metotlar (ortama ve standart sapma, frekans dağılımı) kullanılmıştır.

Sinırlılıklar: Bu araştırmada elde edilen veriler bir üniversite hastanesi verileri ile sınırlıdır. Vulvavajen kanseri tanısı alan az sayıda hasta olduğu için, vulva-vajen kanserine dair istatistiksel hesaplamalar yapılamamıştır. 


\section{BULGULAR}

Çalışma kapsamına alınan 109 vakanın yaş ortalamas1 50,69 $\pm 12,17$ olup \%61,5'inin lise mezunu, \% 61,5'inin ev hanımı ve \%75,2'sinin de evli olduğu belirlenmiştir. Olguların alışkanlıklarına bakıldığında \%36,7'si sigara ve \%86,2'si alkol kullanmadığını ifade etmiştir.

Vakaların \%86,2'sinin beden kitle indeksi (BKI) 30 $\mathrm{kg} / \mathrm{m}^{2}$ ve üzeri \%35,8'inin en az bir kronik bir hastalığı olup \%94,5'inin menarş yaşlarının 11-13 yaş aralığında ve \%46,8'inin menopozda olduğu belirlenmiştir. Araştırma kapsamındaki vakaların obstetrik özelliklerine bakıldığında \%25,7'sinin primipar, $\% 81,6$ 'sının en az bir kez düşük ve \%37,4'ünün en az bir küretaj öyküsü olduğu saptanmıştır.

Tablo 1. Serviks kanserli olguların risk faktörleri ve histopatolojik tiplemeye göre dağılımı $(n=70)$.

\begin{tabular}{|c|c|c|}
\hline Özellikler & $\mathbf{n}$ & $\%$ \\
\hline \multicolumn{3}{|c|}{ Kişisel ve Geçmiş Tıbbi Öykü Risk Faktörleri* } \\
\hline$(40-55$ yaş) & 46 & 65,6 \\
\hline Uzun süre OKS kullanımı ( $>5$ y1l) & 4 & 5,5 \\
\hline Postmenopozal kanama & 7 & 10,0 \\
\hline Anormal vajinal kanama (menoraji-metroraji) & 7 & 10,0 \\
\hline Sürekli akıntı & 16 & 22,9 \\
\hline Postkoital kanama & 40 & $\overline{57,8}$ \\
\hline Kronik enfeksiyonlar & 8 & 11,4 \\
\hline Servikal lezyon & 9 & 12,9 \\
\hline Displazi & 9 & 13,0 \\
\hline Anormal pap smear & 39 & 55,5 \\
\hline CYBH öyküsü & 8 & 12,0 \\
\hline \multicolumn{3}{|c|}{ Yaşam Biçimi ve Çevresel Faktörler* } \\
\hline Erken yaşta cinsel ilişki (<18 y) & 25 & 35,6 \\
\hline Erken yaşta gebelik $(<18 \mathrm{y})$ & 15 & 21,4 \\
\hline Geç yaşta doğum $(35 \mathrm{ve}+)$ & 5 & 6,5 \\
\hline Fazla sayıda gebelik $(3$ ve + ) & 5 & 7,1 \\
\hline Düşük sosyoekonomik düzey & 9 & 12,9 \\
\hline Kötü hijyen koşulları & 45 & 64,3 \\
\hline Diyette vitamin A ve C ve folat yetersizliği & 14 & 20,1 \\
\hline Sigara içimi (günde 10 ve üzeri) & 8 & 11,5 \\
\hline \multicolumn{3}{|l|}{ Histopatolojik Tip } \\
\hline Skuamöz hücreli Karsinom & 42 & 58,6 \\
\hline Servikal adeno karsinom & 17 & 25,4 \\
\hline Berrak hücreli karsinom & 7 & 10,5 \\
\hline Adeno sarkom & 4 & 5,5 \\
\hline
\end{tabular}

*: Birden fazla yanıt verilmiştir.
Kadınların \%64,2'sinin serviks kanseri iken \% 23,9'unun tıbbi tanısının endometrium kanseri \% 11,9'unun over kanseri olduğu belirlenmiştir.

Vakaların başvuru şikayetleri incelendiğinde serviks kanserli vakaların çoğunlukla postkoital kanama (\% $57,8)$ ve anormal pap smear $(\% 55,5)$, endometrium kanserli vakaların postmenopozal kanama $(\% 71,7)$, menoraji-metroraji $(\% 20,5)$ ve over kanserli vakaların da karın şişkinliği (\%54), karın ağrısı $(\% 27,8)$ ve kasık ağrısı $(\% 26,2)$ yakınmaları ile hastaneye başvurdukları saptanmıştır.

Serviks kanserli vakalarda belirlenen risk faktörleri incelendiğinde; \%7,3'ünün ailesinde de serviks kanserli bir birey olup \%65,6'sının 40-55 yaş grubunda, $\% 57,8$ 'inde postkoital kanama, \%55,5'inde anormal pap smear öyküsü ve \%22,9'unda sürekli akıntı ol-

Tablo 2. Endometrium kanserli olguların risk faktörleri ve histopatolojik tiplemeye göre dağılımı $(n=26)$.

\begin{tabular}{|c|c|c|}
\hline Özellikler & $\mathbf{n}$ & $\%$ \\
\hline \multicolumn{3}{|l|}{ Kişisel risk faktörleri* } \\
\hline Postmenapozal dönem & 20 & 76,9 \\
\hline Erken menarj $(<12$ y) & 15 & 57,7 \\
\hline Geç menapoz ( $>50 \mathrm{y})$ & 6 & 23,1 \\
\hline \multicolumn{3}{|c|}{ Geçmiş Tıbbi Öyküye Ait Riskler* } \\
\hline Anormal kanama ya da lekelenme & 18 & 71,7 \\
\hline Postmenopozal kanama & 18 & 71,7 \\
\hline Endometrium hiperplazisi & 16 & 44,6 \\
\hline Hipertansiyon $(>140 / 90 \mathrm{mmHg})$ & 12 & 48,0 \\
\hline Sürekli anormal akıntı & 10 & 38,5 \\
\hline Abdominal ya da pelvik ağrı & 10 & 38,5 \\
\hline Tamoksifen kullanma & 2 & 7,6 \\
\hline Kronik anovulasyon / polikistik over & 2 & 7,6 \\
\hline \multicolumn{3}{|c|}{ Yaşam Biçimi ve Çevresel Faktörler* } \\
\hline Yüksek sosyoekonomik düzey & 11 & 42,3 \\
\hline Düşük parite (bir gebelik) & 7 & 26,9 \\
\hline Nulliparite & 5 & 19,2 \\
\hline Obezite (BKİ: $\geq 29 ;$ şişman) & 8 & 30,8 \\
\hline Yüksek hayvansal yağ içeren diyet & 12 & 46,1 \\
\hline $\begin{array}{l}\text { Karşılanmamış östrojen hormon replas- } \\
\text { man tedavisi }(5>\text { yıl })\end{array}$ & 10 & 38,5 \\
\hline Geçmişte oral kontraseptif kullanma & 9 & 34,6 \\
\hline Geçmişteki rahim içi araç kullanımı & 18 & 69,2 \\
\hline \multicolumn{3}{|l|}{$\begin{array}{l}\text { Histopatolojik Tip } \\
\end{array}$} \\
\hline Endometrioid adenokarsinom & 17 & 65,4 \\
\hline Seröz adenokarsinom & 2 & 7,6 \\
\hline Seröz-endometrioid adenokarsinom & 3 & 11,5 \\
\hline Müsinöz adenokarsinom & 1 & 3,8 \\
\hline Berrak hücreli adenokarsinom & 1 & 3,8 \\
\hline Adeno scuamöz karsinom & 2 & 7,6 \\
\hline Undifferensiye karsinom & - & - \\
\hline
\end{tabular}


duğu görülmüştür. Vakaların \%35,6'sında ilk cinsel aktivite 18 yaş altı olup \%64,3'ü kötü hijyen koşullarına sahip olduğunu ifade etmiştir. Her beş vakadan birinin BKI $30 \mathrm{~kg} / \mathrm{m}^{2}$ üzerinde ve 18 (\%25,7) vakada en az bir kronik hastalık belirlenmiştir. Vakalarda en s1k tespit edilen histolojik tip ise $41(\%$ $58,6)$ olguda bulunan skuamöz hücreli karsinomdur (Tablo 1).

Çalışmamızda endometrium kanserli vakalar risk faktörleri yönünden değerlendirildiğinde; $\% 8,7$ 'sinin ailesinde endometrium kanseri öyküsünün olup \% 38,5'inin BKI $30 \mathrm{~kg} / \mathrm{m}^{2}$ üzerindedir. Vakaların \% 76,9'unun postmenopozal dönemde, \%71,7'sinin postmenopozal kanamal1, \%44,6'sinda endometrial hiperplazi olduğu ve \%48'inin en az bir kronik hastalığı olduğu belirlenmiştir. Yaşam biçimi özelliklerine bakıldığında ise $\% 46,1$ 'i yüksek hayvansal yă içeren diyetle beslendiklerini, \%69,2'si ise geçmişte rahim içi araç kullandıklarını ifade etmişlerdir. Vakalarda en s1k tespit edilen histolojik tip $17(\% 65,4)$ vakada bulunan endometrioid adenokarsinomdur (Tablo 2).

Over kanseri tanısı almış olan 13 vakada risk faktörleri değerlendirildiğinde ise; \%5,5'inin ailesinde de over kanseri öyküsü, \%65'inin tanı alma yaşlarının 40-60 aralığında olup ve \%74,3'ünün geç menopoza girdiği belirlenmiştir. Vakaların \%46,1'i infertilite tedavisi aldığını \%35,4'ü geç yaşta çocuk sahibi olduğunu ve \%20,1'i ise bebeğini emzirmediğini ifade etmiştir. Yaşam biçimi ve çevresel risk faktörleri arasında yine obezite $(\% 54)$ ve yüksek yağ içeren hayvansal gida tüketimi $(\% 22,9)$ dikkat çekmektedir. Primer over kanserli vakaların histopatolojik tipi epitelyal over kanseri (\%54) olarak belirlendi (Tablo 3).

Tablo 3. Over kanserli olguların risk faktörleri ve histopatolojik tiplerine göre dağılımı $(n=13)$.

\begin{tabular}{|c|c|c|}
\hline Overden köken alankanserli olgular $(n=13)$ & $\mathrm{n}$ & $\%$ \\
\hline \multicolumn{3}{|l|}{ Kișisel risk faktörleri* } \\
\hline Anovulasyon ve düzensiz kanamalar & 6 & 46,1 \\
\hline Overlerde fonksiyon bozukluğu & 5 & 38,4 \\
\hline Hazımsızlık ya da GİS şikayeti & 4 & 30,7 \\
\hline Abdominal basınç & 7 & 54,0 \\
\hline Abdominal ya da pelvik kitle & 5 & 38,4 \\
\hline Pelvik radyasyon uygulamas1 & 2 & 15,3 \\
\hline Over kisti & 5 & 38,4 \\
\hline Dismenore & 2 & 15,3 \\
\hline Geç menapoz (50 y ve sonras1) & 10 & 74,3 \\
\hline Erken menarş & 4 & 30,7 \\
\hline Geç yașta gebelik $(\geq 35 \mathrm{y})$ & 5 & 35,4 \\
\hline Geçmiş tıbbi öyküye ait riskler (40-60 yaş) & 8 & 65,0 \\
\hline \multicolumn{3}{|l|}{ Yașam Biçimi ve çevresel faktörler* } \\
\hline İnfertilite & 6 & 46,1 \\
\hline Nulliparite (hiç doğum yapmamış) & 2 & 15,3 \\
\hline Düşük parite (bir gebelik) & 5 & 35,4 \\
\hline Geç yaşta çocuk doğurma $(\geq 35)$ & 5 & 35,4 \\
\hline Bebeğini emzirmeme & 3 & 20,1 \\
\hline Yüksek sosyoekonomik düzey & 5 & 35,4 \\
\hline Fertilite ilaçları kullanma & 6 & 46,1 \\
\hline Yüksek hayvansal yağ içeren diyet & & 22,9 \\
\hline Süt ve süt ürünlerinden fazla tüketme & 4 & 30,7 \\
\hline Sigara içme ( $\geq 10$ adet /gün) & 2 & 15,3 \\
\hline Fazla kahve tüketimi & 4 & 30,7 \\
\hline Obezite (BKİ: $\geq 29 ;$ șișman) & 7 & 54,0 \\
\hline \multicolumn{3}{|l|}{ Histopatolojik tip } \\
\hline Epitelyal over kanser & 7 & 54,0 \\
\hline Papiller seröz kistadenokarsinom & 1 & 7,6 \\
\hline Müsinöz adenokarsinom & 1 & 7,6 \\
\hline Clear cell kanser & 2 & 15,3 \\
\hline Endometrioid kanser & - & - \\
\hline Transisyonel hücreli karsinom & - & - \\
\hline Undifferansiye karsinom & - & - \\
\hline Germ hücreli over kanser & 2 & 15,3 \\
\hline Sekskord stromal hücreli tümör & - & - \\
\hline
\end{tabular}

*: Birden fazla yanıt verilmiştir. 


\section{TARTIŞMA VE SONUÇ}

$\mathrm{Bu}$ çalışmada son üç yıl içinde endometrium, over ve serviks kanseri tanısı almış olan 109 hasta ile ilgili veriler, risk faktörleri yönünden değerlendirilmiştir. Çalışmamızda vakaların \%64,2'sinin serviks kanseri iken \%23,9'unun tıbbi tanısının endometrium kanseri \%11,9'unun over kanseri olduğu belirlenmiştir. Serviks kanseri tanısı almış kadınların \% 25,7'si BKI $30 \mathrm{~kg} / \mathrm{m} 2$ üzerinde iken bu oran endometriyum kanserinde $\% 38,5$, over kanserinde $\% 54$ olarak tespit edilmiştir. Ayrıca hipertansiyon ve diyabetin serviks ve endometriyum kanseri için önemli bir risk faktörü olduğu belirlenmiştir.

Jinekolojik kanserler, kadınlarda en sık görülen ilk on kanser türünün içinde olup hem yüksek morbidite ve mortalite yükü hem de önlenebilir olması nedeniyle halk sağlığı açısından önemli sorunlardır. ${ }^{6}$ Coğrafi dağılımı kıtalara göre değişmektedir; Sahra altı Afrika ülkeleri, güney Amerika ülkeleri gibi ekonomik açıdan gelişmişlik indekisine göre kötü olan ülkelerde jinekolojik kanserler daha sık görülmektedir. ${ }^{7}$

Dünya genelinde kadınlar arasında en sık görülen kanserler içinde serviks kanseri \%13,1 ile dördüncü sırada olup, jinekolojik kanserlerde ise ikinci sırada yer almaktadır. ${ }^{15}$ Her yıl yarım milyondan fazla kadına rahim ağzı kanseri teşhisi konuluyor olup hastalık dünya çapında 300.000 'den fazla ölümle sonuçlanmaktadır. ${ }^{16}$

Türkiye kanser istatistiklerinde ilk 10 kanserin içine korpus uteri, over ve serviks uteri kanseri surasiyla \% $5 \% 3,7$ ve $\% 2,5$ oranlarıyla girmektedir. ${ }^{6}$ Ege bölgesinde yapılan bir çalışmada ilk 10 kanser içine korpus uteri, serviks uteri ve over kanseri sirasiyla $\% 6,6$ $\% 5,2$ ve $\% 3,5$ oranlarıyla yer almaktadır. Jinekolojik kanserlerin içinde korpus uteri kanseri \%41,6 ile ilk sıradadır. ${ }^{17}$

Asghari N.'nin ${ }^{18}$ Konya'da yaptığı çalışmada hastaları $\% 56,1$ 'inin endometrium, $\% 15,2$ 'sinin serviks ve $\% 27,3$ 'ünün over kanseri olduğu tespit edilmiştir. Turgut ve ark. ${ }^{19}$ Diyarbakır'da yaptıkları çalışmaya göre; hastaların $\% 44,7$ 'si over, $\% 30,5$ 'i endometriyum, $\% 21$ 'i serviks, $\% 1,8$ vulva kanseri tanısı almıştır. Ülkemizde Human Papilloma Virüsü (HPV) ve smear testi ile serviks kanseri taraması yapılması erken tanı için olumlu sonuçlar vermekte ise de çeşitli bölgelerinde yapılan çalışmalarla karşılaştırdığımızda vakalarımızın, serviks kanseri oranı diğer çalışmalardan daha yüksektir, endometrium kanseri oranı ise benzer veya düşük ve over kanseri oranı düşük bulunmuştur.

Tanıya dair elde edilen farklı sonuçlar özellikle böl- gemizdeki erken yaş evliliklerinin fazla olması ve yetersiz servikal smear taramaları gibi çevresel ve kültürel etmenlerin etkisiyle erken ya da geç yaşta tanı almaktan kaynaklanıyor olabilir.

Çalışmamızda BKI $30 \mathrm{~kg} / \mathrm{m}^{2}$ 'nin üzerinde olanların oranı serviks kanserinde $\% 25,7$ endometriyum kanserinde $\% 38,5$ ve over kanserinde $\% 54$ olarak belirlenmiştir. Kronik hastalık oranlarına baktığımızda serviks kanserinde vakaların $\% 25,7$ 'sinin diyabet ve hipertansiyon gibi en az bir kronik hastalığı bulunurken endometriyum kanserinde bu oran $\% 48$ 'dir. Dünyada ve ülkemiz genelinde kanserin yanı sıra obezite, hipertansiyon ve diyabet gibi kronik hastalıkların prevalansı giderek artmaktadır. Dünya Sağlık Örgütü (DSÖ)'nün Bulaşıcı Hastalıkların Önlenmesi ve Kontrolüne İlişkin Küresel Eylem Planı 2013-2020'de gönüllü küresel hedefleri arasında kanser, kardiyovasküler hastaliklar ve diyabet nedeniyle gerçekleşen ölümlerde $\% 25$ oranında azalma ile obezite durdurulması yer almaktadır. ${ }^{20}$ Yapılan çalışmalar bulgularımızı destekler nitelikte olup obez kadınlarda BKI ve bel-kalça oranının artması kadınların jinekolojik kanseri riski ile ilişkili bulunmuştur. ${ }^{10,21-24}$ Yine epidemiyolojik çalışmalarda hipertansiyon ve diyabetin sedanter yaşam, alkol kullanımı, obezite, sigara içme vb. risk faktörlerini paylaşmaları nedeni ile serviks ve endometriyum kanseri riskini arttırdığı belirlenmiştir. ${ }^{25,26}$ Çalışmamızda yine vakalarımızın yaşam biçimi özelliklerine bakıldığında endometriyum kanserli vakaların \% 46,1'inin, over kanserli vakaların ise \%22,9'inin ise yüksek hayvansal yağ içeren diyetle beslendiklerini görülmüştür. Literatürde de yüksek yağlı ve et diyetlerinin bu kanser türlerinin riskinin artmasıyla ilişkilendirilmiştir. $22,24,27$

Obezite, hipertansiyon, diyabetin serviks ve endometriyum kanseri için önemli bir risk faktörü olması gelecekte ülkemiz için de önemli bir sağlık sorunu olacağını düşündürmektedir.

Serviks kanserinde önemli risk faktörlerinden birisi de kötü hijyeni olarak bilinmektedir. ${ }^{28}$ Genital bölge hijyenine özen gösterilmesi gelişebilecek genital yol enfeksiyonlarının ve dolayısıyla serviks kanserinin önlenmesi açısından önemlidir. Çalışmamızda vakaların \%64,3'ünde hijyen yetersizliği saptanmıştır.

Çalışmamızdaki endometrial kanserli vakaların büyük çoğunluğunu menopozdaki kadınlar oluşturmaktadır. Postmenopozal kanama ise en sik başvuru nedeni olarak bulunmuştur.

Uterus kanseri serviks kanserine göre daha ileri yaşlarda görülmektedir. Endometrial kanserli kadınların yaklaşı \% \%9'ında anormal uterin kanama vardır; 
menopoz sonrası kanama ile başvuranların \%33'üne endometrial kanser teşhisi konulur. ${ }^{29}$ Hastalığın erken dönemde iken semptom göstermesi, hastalığın erken evrelerde tanınmasının en önemli sebebidir. Çalışmamızda over kanserli vakaların başvurudaki en sık semptomları karın ağrısı ve karında şişkinliktir. Literatürde sessiz katil olarak tanımlanan over kanseri, semptom gösterdiğinde ise ileri evrededir. ${ }^{28}$ Kadınların maling jinekolojik semptomları yönünden bilinçlendirilmesi veya herhangi bir jinekolojik semptomla muayeneye gelen kadınlar over kanseri taraması için iyi bir pelvik muayene ve ultrasonografi ile değerlendirilmesi elimizdeki tek geçerli yöntemdir.

Laktasyon, ovulasyonu baskıladığı için over kanseri riskini azaltmaktadır. ${ }^{11}$ Çalışmamızda 5 vakadan birinin çocuklarını emzirmediği belirlenmiştir. Literatürde fertilite sorununa yönelik ilaç kullanan kadınlar arasında over kanseri riskinin 2-3 kat arttığ belirlenmiştir. $^{30}$ Olgularımızın $\% 46,1^{\prime} \mathrm{i}$ infertilite tedavisi görmüştür.

$\mathrm{Bu}$ çalışmanın sonucunda vakaların başvuru yakınmaları ve risk faktörleri ile ilgili elde edilen veriler değerlendirildiğinde; özellikle çevresel risk faktörleri ve kişinin yaşam tarzının jinekolojik kanserler üzerinde önemli etkisi olduğu saptanmıştır. Bu risk faktörlerinin belirlenmesi, yüksek risk altındaki kadınlarda hedeflenen önleme stratejilerinin geliştirilmesinde oldukça önemlidir. Buna göre kadın sağlığ 1 alanında çalışan sağlık profesyonelleri tarafından sağlıklı alışkanlık ve davranışlara yönelik, kapsayıcı eğitim, etkinlik ve toplumu bilinçlendirme kampanyaları oluşturulmalıdır. Riskli bireyler sıklıkla takip edilmeli gerekirse bu hastalara koruyucu cerrahi uygulanabilir. Özellikle serviks kanseri tanı ve tedavi şansı göz önüne alındığında; etkin tarama çalışmaları yapılmalı, toplumda riskli gruptaki kadınların tamamının pap-smear taraması yapılması amaçlanmalıdır. Bunun yanında günümüzde jinekolojik kanserler ile obezite, hipertanisyon ve diyabet gibi kronik hastalıklar giderek artma ve birbirini etkileme eğilimi gösterdiğinden, jinekolojik kanser ve kronik hastalıkların beraber değerlendirilmesi etkili olacaktır. Ayrıca meme kanseri ve jinekolojik kanser tanısı olan kadınlar genetik yatkınlık yönünden taranmalıdir.

Etik Komite Onayı: Bu araştırma için Balıkesir Üniversitesi Tıp Fakültesi Klinik Araştırmalar Etik Kurul Başkanlığı'ndan (Tarih=22.07.2020, karar no $=2020 / 115)$ ve ilgili kurumdan yazılı izin alınmıştir.
Çıkar Çatışması: Yazarlar çıkar çatışması bildirmemişlerdir.

Yazar Katkıları: Fikir - MiT; Veri toplanması ve/veya işlemesi - SA, PP; Analiz ve/veya yorum - MIT; Yazıyı yazan - SA.

Hakem Değerlendirmesi: Dış bağımsız.

\section{KAYNAKLAR}

1. Yastıbaş C, Dirik G. Kanser ve farkındalık temelli müdahale programları: sistematik derleme. Psikiyatride Güncel Yaklaşımlar Dergisi. 2018;10(3):375-393. doi:10.18863/pgy.357261

2. Siegel RL, Miller KD, Jemal A. Cancer statistics 2017. CA Cancer J Clin. 2017;67(1):7-30. doi: $10.3322 /$ caac. 21387

3. Ergin A, Özdilek R, Dutucu N. 2012-2017 yılları arasında kadınlarda görülen kanser türleri ve dağılımları: bir üniversite hastanesi örneği. Kadın Sağlığı Hemşireliği Dergisi. 2019;5(1):1-21.

4. Incidence, Mortality and Prevalence By Cancer Site. http://gco.iarc.fr/today/data/factsheets/ populations/90 0-world-fact-sheets.pdf. Erişim tarihi 09 Aralık 2020.

5. American Cancer Society. Cancer Facts \& Figures 2018. https:// www. cancer.org/ content/ dam/ cancer-org/research/cancer-facts-and-statistics/ annual-cancer-facts-and- Figures/ 2018/ leadingsites-of-new-cancer-cases-and-deaths-2018estimates.pdf. Erişim tarihi 09 Aralık 2020.

6. Türkiye Kanser İstatistikleri. T.C. Sağlık Bakanlığı Türkiye Halk Sağlığı Genel Müdürlüğü Kanser Daire Başkanlığı, 2016. https:// hsgm.saglik.gov.tr/tr/kanser-istatistikleri/ yillar/2016-yili-turkiye-kanser-istatistikleri.html. Erişim tarihi 09 Aralık 2020.

7. Bray F, Ferlay J, Soerjomataram I, Siegel RL, Torre LA, Jemal A. Global cancer statistics 2018: GLOBOCAN estimates of incidence and mortality worldwide for 36 cancers in 185 countries. Cancer J Clin. 2018;68(6):394-424. doi:10.3322/caac. 21492

8. Gültekin $M$, Dündar S, Küçükyıldız I, ve ark. Survival of gynecological cancers in Turkey: where are we at? J Gynecol Oncol. 2017;28(6): e85.

9. Pınar I, Algıer L, Doğan N, Kaya N. Determination of the risk factors in individuals with gynecological cancer. Int J Hematol Oncol Stem Cell Res. 2008;18(4):208-216.

10. Braun M, Overbeek-Wager EA, Grumbo JR. Diagnosis and management of endometrial cancer. Am Fam Physician. 2016;93(6):468-474. 
11. Raglan O, Kalliala I, Markozannes G, ve ark. Risk factors for endometrial cancer: an umbrella review of the literature. Int J Cancer. 2019;145 (7):1719-1730. doi:10.1002/ijc.31961

12. Vecchia C. Ovarian cancer: epidemiology and risk factors. Eur J Cancer Prev. 2017;26(1):5562. doi:10.1097/CEJ.0000000000000217

13. Kaya C, Üstü Y, Özyörük E, Aydemir Ö, Şimşek Ç, Şahin AD. Sağlık çalışanlarının kanser taramaları hakkındaki bilgi, tutum ve davranışlarının değerlendirilmesi. Ankara Med J. 2017;17 (1):73-83. doi:10.17098/amj.95107

14. Baskın Y, Ellidokuz H. Kadın ve kanser. Türkiye Klinikleri J Public Health-Special Topics. 2015;1 (1):45-50.

15. World Health Organization International Agency for Research on Cancer. Cancer Today. https:// gco.iarc.fr/today. Erişim Tarihi 10 Aralık 2020.

16. Cohen PA, Jhingran A, Oaknin A, Denny L. Cervical cancer. Lancet. 2019;393(10167):169-182. doi:10.1016/S0140-6736(18)32470-X

17. Haydaroğlu A, Özsaran Z, Şanlı A, ve ark. Ege üniversitesi hastanesinde jinekolojik kanserlerin epidemiyolojik ve genel sağ kalım özellikleri. Ege Tıp Derg. 2019;58 (ek say1):26-32.

18. Ashgari N. Bir Üniversite hastanesinde tedavi olan jinekolojik onkolojik vakaların değerlendirilmesi. Selçuk Üniversitesi Sağlık Bilimleri Enstitüsü Halk Sağlığı Anabilim Dalı, Yüksek Lisans Tezi. Konya, Türkiye. 2014.

19. Turgut A, Özler A, Sak ME, ve ark. Jinekolojik kanserli olguların retrospektif analizi: 11 yıllık deneyim. JCEI. 2012;3(2):209-213.

20. Dünya Sağlık Örgütü. Bulaşıcı Olmayan Hastalıkların Önlenmesine ve Kontrolüne İlişkin Küresel Eylem Planı 2013-2020. https:// sbu.saglik.gov.tr/Ekutuphane/kitaplar/bula\%C5\% 9F\%C4\%B1c\%C4\%B1\%20olmayan \%20hastal\% C4\%B1klar.pdf. Erişim tarihi 10 Aralık 2020.

21. Clarke MA, Fetterman B, Cheung LC, ve ark. Epidemiologic evidence that excess body weight increases risk of cervical cancer by decreased detection of precancer. J Clin Oncol. 2018;36 (12):1184-1194. doi:10.1200/JCO.2017.75.3442

22. Dikmen S, Tavşanlı N. Serviks kanseri taraması ile obezite, hipertansiyon ve diyabet bulgularının karşılaştırılması. Life Sciences. 2020;15(3):1931. doi:10.12739/NWSA.2020.15.3.4B003.2

23. Sarı O, Aydoğan Ü. Obezite ve kanserler. Türkiye Klinikleri Aile Hekimliği Özel Dergisi. 2015;6(3):90-95.

24. Bhaskaran K, Douglas I, Forbes H, ve ark. Body- mass index and risk of 22 specific cancers: a populationbased cohort study of 24 million UK adults. Lancet. 2014;384(9945):755-765. doi:10.1016/S0140-6736(14)60892-8

25. Souza VBD, Silva EN, Ribeiro ML, Martins WDA. Hypertension in patients with cancer. Arq Bras Cardiol. 2015;104(3):246-252. doi:10.5935/ abc. 20150011

26. Anastasi E, Filardi T, Tartaglione S, Lenzi A, Angeloni A, Morano S. Linking type 2 diabetes and gynecological cancer: An introductory overview. Clin Chem Lab Med. 2018;56(9):14131425. doi:10.1515/cclm-2017-0982.20

27. Dunneram Y, Greenwood DC, Janet E. Diet, menopause and the risk of ovarian, endometrial and breast cancer. Cade Proc Nutr Soc. 2019;78 (3):438-448. doi:10.1017/S0029665118002884

28. Ayhan A, Durukan T, Günalp S. Temel Kadın Hastalıkları ve Doğum Bilgisi. 2. Baskı. Ankara, Güneş Tip Kitapevi; 2008.

29. Clarke MA, Long BJ, Morillo AD, Arbyn M, Bakkum-Gamez JN, Wentzensen N. Association of endometrial cancer risk with postmenopausal bleeding in women: A systematic review and meta-analysis. JAMA Intern Med. 2018;178 (9):1210-1222. doi:10.1001/ jamainternmed.2018.2820

30. Koushik A, Grundy A, Abrahamowicz M, ve ark. Hormonal and reproductive factors and the risk of ovarian cancer. Cancer Causes Control. 2017;28(5):393-403. doi:10.1007/s10552-0160848-9 